\title{
Topoisomerase II- $\alpha$ Expression in Different Cell Cycle Phases in Fresh Human Breast Carcinomas
}

Kenneth Villman, M.D., Elisabeth Ståhl, M.S., Göran Liljegren, M.D., Ph.D., Ulf Tidefelt, M.D., Ph.D., Mats G. Karlsson, M.D., Ph.D.

Departments of Oncology (KV), Pathology (ES, MGK), Surgery (GL), and Medicine (UT), Örebro University Hospital, Örebro, Sweden; and Karolinska Institute (UT), Stockholm, Sweden

Topoisomerase II- $\alpha$ (topo II $\alpha$ ) is the key target enzyme for the topoisomerase inhibitor class of anticancer drugs. In normal cells, topo II $\alpha$ is expressed predominantly in the S/G2/M phase of the cell cycle. In malignant cells, in vitro studies have indicated that the expression of topo II $\alpha$ is both higher and less dependent on proliferation state in the cell. We studied fresh specimens from $\mathbf{5 0}$ cases of primary breast cancer. The expression of topo II $\alpha$ in different cell cycle phases was analyzed with twoparameter flow cytometry using the monoclonal antibody SWT3D1 and propidium iodide staining. The expression of topo II $\alpha$ was significantly higher in the $S / G 2 / M$ phase of the cell cycle than in the G0/G1 phase in both DNA diploid and DNA nondiploid tumors. In 18 of 21 diploid tumors, and in 25 of 29 nondiploid tumors, $>50 \%$ of the topo II $\alpha$-positive cells were in the G0/G1 phase. This significant expression of topo II $\alpha$ in the G0/G1 phase of the cell cycle may have clinically important implications for treatment efficacy of topoisomerase II inhibitors.

KEY WORDS: Breast cancer, Cell cycle, DNA flow cytometry, Topoisomerase II $\alpha$.

Mod Pathol 2002;15(5):486-491

Breast cancer is the most common cancer among women in Sweden and in the United States, and the disease is fatal to every fourth woman despite wide use of adjuvant chemotherapy (1-3). The limited efficacy of chemotherapy is due to intrinsic or acquired resistance to the drugs in use. Anthracyclines are the most active chemotherapeutic agents in advanced breast cancer (4) and are today in-

Copyright (C) 2002 by The United States and Canadian Academy of Pathology, Inc.

VOL. 15, NO. 5, P. 486, 2002 Printed in the U.S.A.

Date of acceptance: January 23, 2002.

This study was supported by grants from the Research Committee of Örebro County Council, Sweden.

Address reprint requests to: Kenneth Villman, M.D., Department of Oncology, Örebro University Hospital, S-701 85 Örebro, Sweden; e-mail: kenneth.villman@orebroll.se; fax: 46-19-101768. cluded in most adjuvant chemotherapy regimens for breast cancer. Anthracyclines belong to the anticancer agents called topoisomerase (topo) II inhibitors.

Topoisomerases are enzymes, present in the nuclei in mammalian cells, that regulate topological changes in DNA that are vital for many cellular processes such as replication and transcription (5). They perform their function by introducing transient protein-bridged DNA breaks on one (topoisomerase I) or both DNA strands (topoisomerase II; 6). There are two isoenzymes of topoisomerase II, with genetically and biochemical distinct features. Topoisomerase II- $\alpha$ (topo II $\alpha$ ), with a molecular weight of $170 \mathrm{kd}$, is located on chromosome 17 (7), and topoisomerase II- $\beta$ (topo II $\beta$ ), with a molecular weight of $180 \mathrm{kd}$, is located on chromosome 3 (8). Topo II $\alpha$ is the primary drug target for anthracyclines $(6,9)$.

Topoisomerase II inhibitors inhibit the rejoining step in the breakage-rejoining cycle of topo II $\alpha$ and thereby shift the equilibrium toward a key covalent reaction intermediate termed the cleavable complex (10). This leads to double-stranded DNA breaks, which can, by a partly unknown mechanism, lead to cell death (11). In vitro studies on cell lines from different human malignancies has shown that sensitivity to topoisomerase II inhibitors is dependent on the cellular level of topo II $\alpha$ (12-14).

Topo II $\beta$ is expressed relatively constantly throughout the cell cycle in both normal and transformed cells $(15,16)$. In cell lines, it has been shown that in normal cells, topo II $\alpha$ is a marker of proliferation and that expression is restricted to S and G2/M phases of the cell cycle, whereas in transformed cells, the topo II $\alpha$ expression is both higher and less dependent on proliferation state in the cell $(15,17-21)$. The altered topo II $\alpha$ distribution may be caused by prolonged intracellular half-life of topo II $\alpha$ associated with the malignant transformation (17). This dysregulation of the expression of topo II $\alpha$ in the cell cycle in malignant cells may have implications for the efficacy of treatment with topoisomerase II inhibitors. 
There is today little information regarding topo II $\alpha$ expression related to different cell cycle phases in human neoplasms. A study on ovarian cancer with two-parameter flow cytometric analysis has detected topo II $\alpha$-positive cells in the G1 phase in 14 of 29 cases (22).

The aim of the present study was to examine the distribution of topo II $\alpha$ in the different cell cycle phases with two-parameter flow cytometry (FCM) in fresh human breast carcinomas.

\section{MATERIALS AND METHODS}

\section{Patients}

Material from 50 tumors from 49 women operated on at Örebro University Hospital was used in this study. All breast cancer samples where sent fresh from the operation theater to the Department of Pathology. Only patients with tumor size big enough to allow adequate material for routine histology, DNA analysis, estrogen receptor and progesterone receptor determinations, and FCM for topo II $\alpha$ were included.

Patient age at operation ranged from 33 to 94 years, with a median age of 61 years. All tumors were invasive breast carcinomas. Tumor characteristics are shown in Table 1. No patient had received preoperative chemotherapy, hormonal therapy, or radiotherapy. Patients were given oral and written information regarding the study, and informed consent was obtained.

\section{Preparation of Fresh Breast Tumor Tissue}

The breast tumor samples were stored at $4^{\circ} \mathrm{C}$ in $0.05 \mathrm{~m}$ phosphate buffered saline (PBS) and pre-

TABLE 1. Characteristics of the 50 Breast Carcinomas

\begin{tabular}{lrr}
\hline & Number & $\%$ \\
\hline Tumor size & 16 & 320 \\
pT1 & 32 & 64 \\
pT2 & 2 & 4 \\
pT3 & 43 & 86 \\
Histologic type & 3 & 6 \\
Ductal & 4 & 8 \\
Lobular & & \\
Other & 9 & 18 \\
Tumor grade & 25 & 50 \\
1 & 16 & 32 \\
2 & & \\
3 & 39 & 78 \\
Estrogen receptor status & 11 & 22 \\
Positive & & \\
Negative & 21 & 42 \\
Ploidy status & 29 & 58 \\
Diploid & & \\
Nondiploid & 26 & 52 \\
Axillary nodal status & 22 & 44 \\
pN0 & 22 \\
pN1 & & 4 \\
ND & &
\end{tabular}

${ }^{a}$ Using the Elston modification of the Bloom and Richardson system.

${ }^{\mathrm{b}} \mathrm{ND}$, axillary node dissection not done. pared within 18 hours of excision. Fresh breast tissue was mechanically disaggregated with Medimachine (ConsulT.S., Rivalta di Torino, Italy) in $0.05 \mathrm{M}$ PBS for 1-2 minutes. The cell suspension was filtered through a $40-\mu \mathrm{m}$ filter and centrifuged at 300 $\times g$ for 5 minutes. After one wash in PBS the cells were diluted to a concentration of $10 \times 10^{6} / \mathrm{mL}$ in 0.05 м PBS.

\section{Determination of S-Phase Fraction and Ploidy}

A regular DNA staining with DNAcon 3 tubes (ConsulT.S.) was performed. The tubes contained a dehydrated buffer (lysing agent, RNAse and cromatin stabiliser). Propidium iodide solution (PI) was added and the tube left at room temperature for 5 minutes in the dark. Two different control cells, chicken and salmon, were added to $1 \times 10^{6}$ sample cells and then incubated for 1 hour in an ice bath in the dark.

The stained nuclei were analyzed in a FACScan equipped with a 488-nm argon laser (Becton Dickinson, Immunocytometry Systems, CA) with CellQuest (Becton Dickinson) software. The DNA analysis was based on 15000 events. To calculate DNA ploidy and S-phase fraction (SPF), Modfit (Becton Dickinson) software was used. Tumors were defined as either diploid (one stemline) or nondiploid (two or more cell populations; 23). The SPF was compared with that of the total number of cells expressing topo II $\alpha$. SPF was technically feasible in $82 \%(41 / 50)$ of the tumors.

\section{Flow Cytometry Topoll $\alpha$ Analysis}

Simultaneous measurement of topo II $\alpha$ and DNA content was done by two-parameter FCM. After $1 \times$ $10^{6}$ cells was added to each of two tubes, the tubes were incubated with $600-\mu \mathrm{L}$ of lysing solution $(0.5 \%$ Triton X-100 [Sigma Chemical Co, St. Louis, MO], $1 \%$ BSA [Life Technologies, Paisley, Scotland], and $0.2 \mu \mathrm{g} / \mathrm{mLEDTA}$ [Sigma] in $0.05 \mathrm{~m}$ PBS), $\mathrm{pH}$ 8.6. The cells were incubated for 10 minutes in an ice bath in the dark. The nuclei were fixed in $2 \mathrm{~mL}$ of $-20^{\circ} \mathrm{C}$ $99.8 \%$ methanol pa (J.T. Baker. Deventer, Holland) for 10 minutes in an ice-bath in the dark. After one wash with $0.05 \mathrm{M}$ PBS, the tubes were centrifuged for 5 minutes at $300 \times g$. Topo II $\alpha$ clone SWT3D1 IgG1 $\kappa$ (DAKO, Glostrup, Denmark; 1:100) was added to one of the tubes. After incubation, a FITCconjugated rat anti-mouse (RAM) antibody (DAKO; 1:50) was added to both tubes and incubated, followed by another incubation with $400 \mu \mathrm{L}$ of PI (10 $\mu \mathrm{g} / \mathrm{mL}$; Sigma), with RNAse (200 $\mu \mathrm{g} / \mathrm{mL}$; Sigma). The last three incubations were performed for 30 minutes in an ice bath in the dark.

The stained nuclei were analyzed in a FACScan equipped with a 488-nm argon laser (Becton Dickinson) and CellQuest (Becton Dickinson) software. 

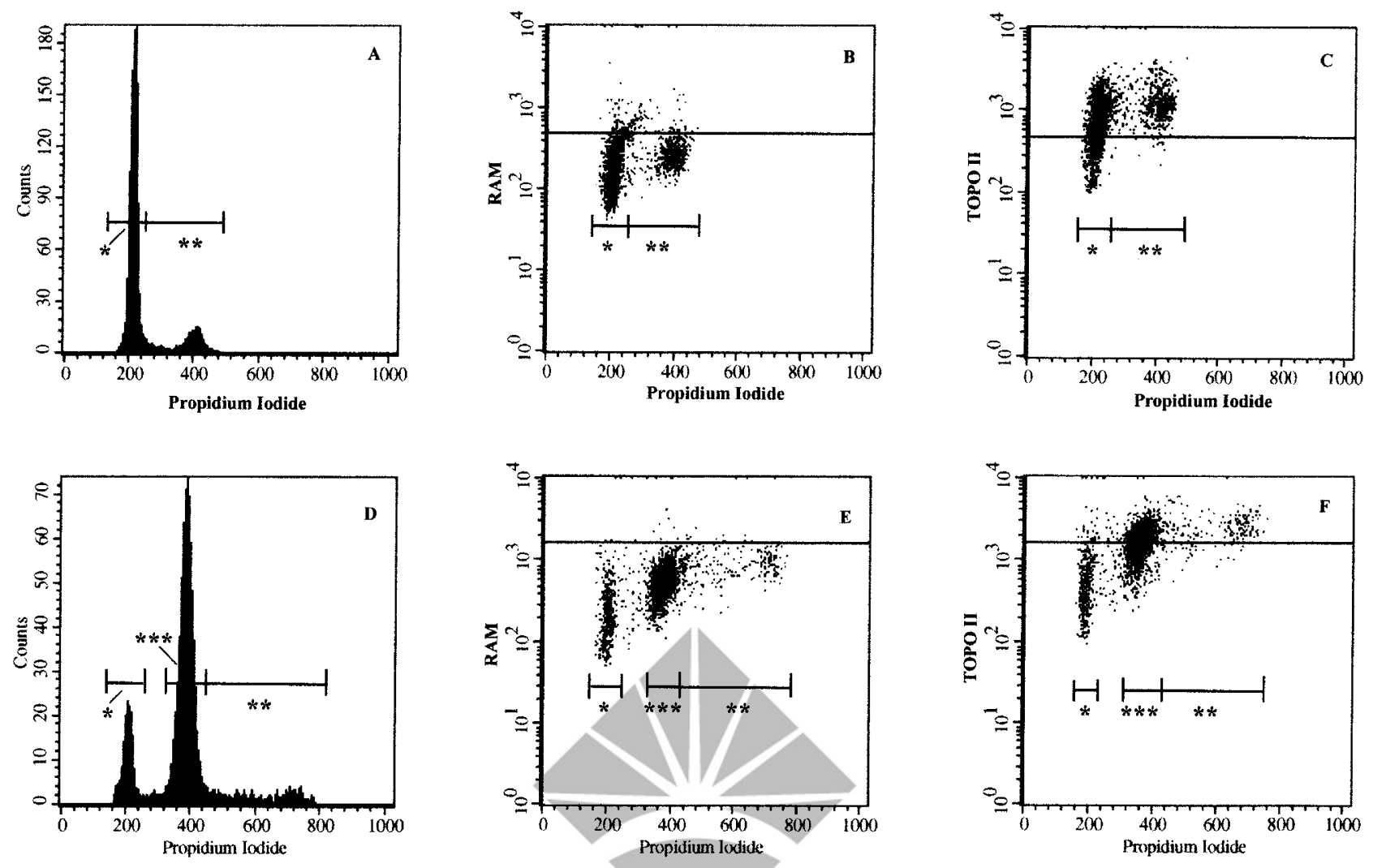

FIGURE 1. Flow cytometric analysis of topo II $\alpha$ and DNA contents in fresh breast carcinomas. The DNA content of the investigated nuclei, reflecting the cell cycle phase, was determined after incubation with propidium iodide and RNAse. (A and D) show DNA histograms used for separation of the different cell cycle phases. A-C, tumor with diploid DNA content showing cells in G0/G1 phase (*) and S/G2/M phase (**). D-F, tumor with nondiploid DNA content showing diploid cells in G0/G1 phase (*), nondiploid cells in G0/G1 phase (***), and cells in S/G2/M phase (**). (B and E) represent negative controls with FITC-labeled rat anti-mouse antibody (RAM) only. The cutoff limit for topo II $\alpha$ positivity was set for each population based on the negative control.

The two-parametric analysis was based on 5000 events. The green fluorescence of FITC was recorded as the total amount of detected topo II $\alpha$, and the red fluorescence of PI was recorded as the total amount of DNA.

In both the analysis of the total topo $\mathrm{H} \alpha$ expression and of the expression in the separate cell cycle phases, the cutoff limits were set individually on the negative control samples according to the appearance of the scatterplot. The percentage of background events in the negative control was subtracted from the percentage of true-positive cells. The separation of the different cell cycle phases was

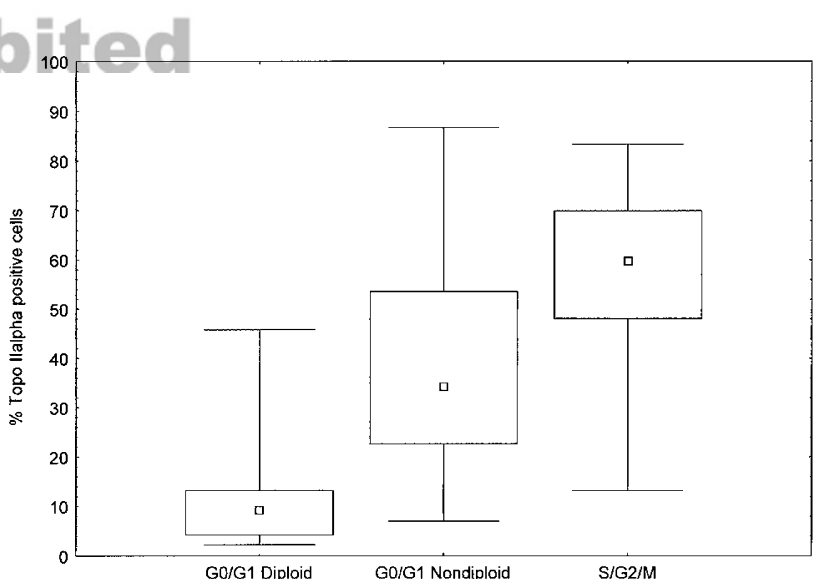

FIGURE 3. Percentage of topo II $\alpha$-positive cells in diploid cells in G0/G1 phase, nondiploid cells in G0/G1 phase, and nondiploid cells in S/G2/M phase in 29 nondiploid breast tumors. The upper and lower quartiles and the median values are depicted as box plots. Whiskers indicate maximum and minimum values.

\section{Prohilb}

FIGURE 2. Percentage of topo II $\alpha$-positive cells in G0/G1 phase and $\mathrm{S} / \mathrm{G} 2 / \mathrm{M}$ phase in 21diploid breast tumors. The upper and lower quartiles and the median values are depicted as box plots. Whiskers indicate maximum and minimum values.

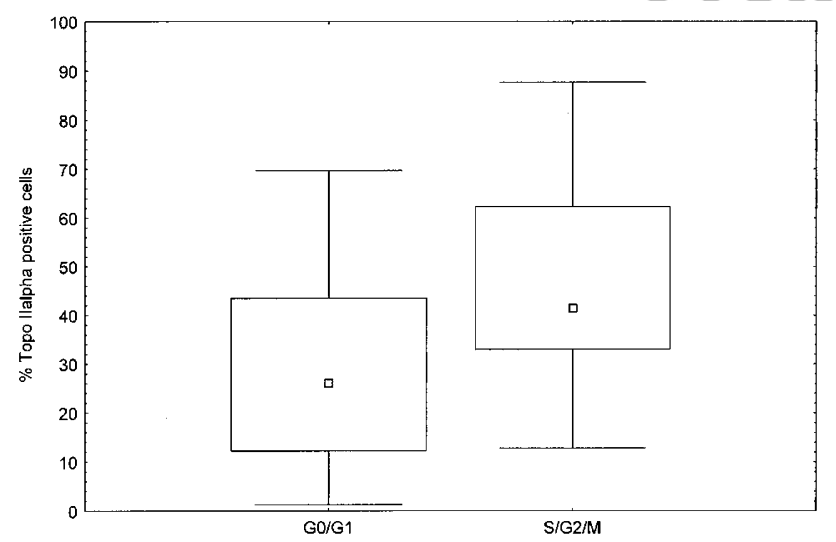

488 


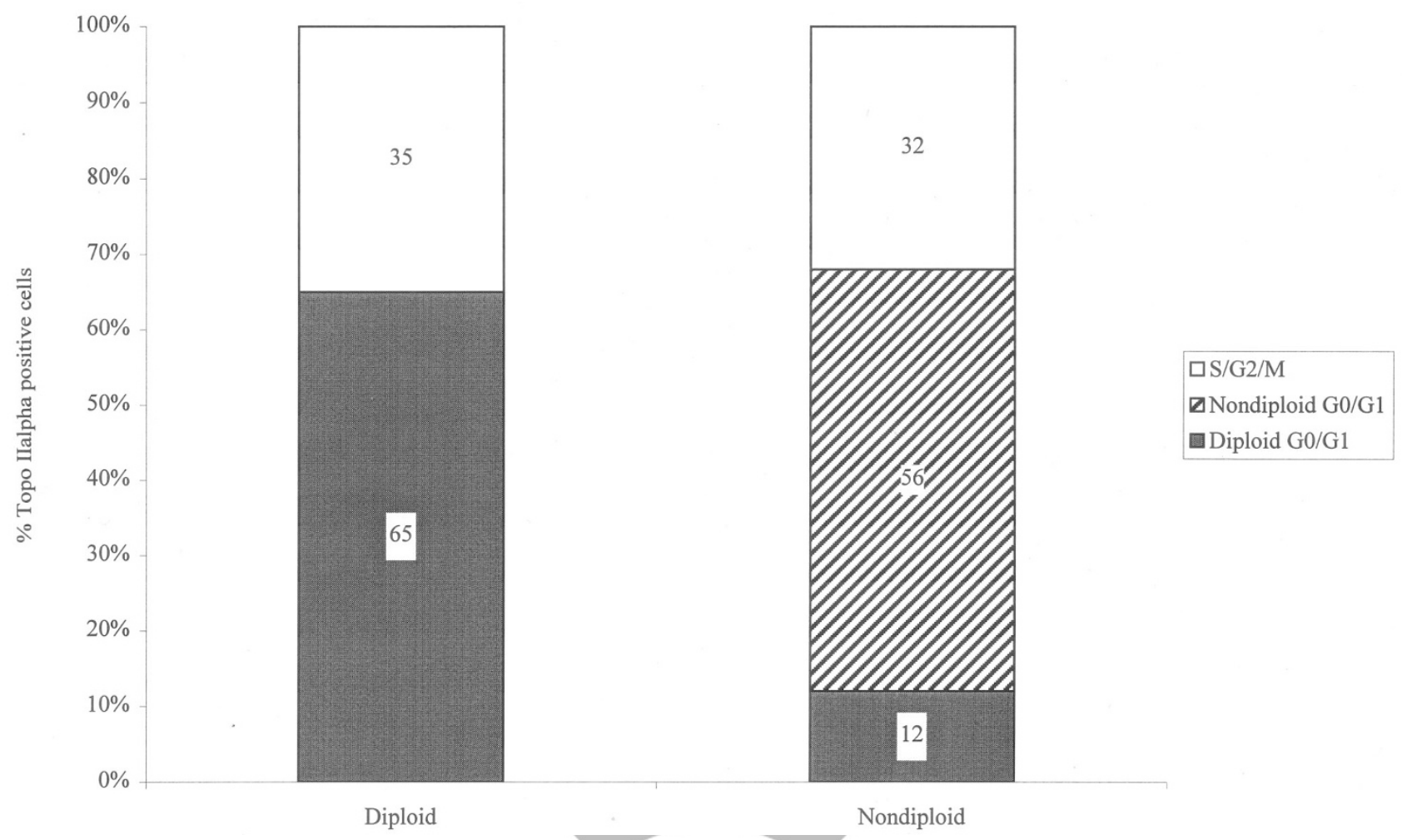

FIGURE 4. Median distribution of the topo II $\alpha$-positive cells in different cell cycle phases in 21 diploid and 29 nondiploid breast tumors.

done from the DNA histogram, as illustrated in Figure 1.

\section{Statistical Methods}

Statistica software (StatSoft, OK) was used for all calculations. Values are presented as the median and difference between upper and lower quartiles (interquartile range, IQR), or as the mean and standard deviation (SD). Difference in proportion of topo II $\alpha$-positive cells between diploid and nondiploid tumors was tested by the Mann-Whitney test. Correlation between the proportion of topo II $\alpha$-positive cells and SPF was determined by the Spearman's rank correlation. Difference in expression of topo II $\alpha$ between cells in G0/G1 phase and S/G2/M phase in diploid tumors was tested by the Wilcoxon matchedpairs test. The three group analysis in nondiploid tumors was done with Friedman ANOVA test and posthoc test with Wilcoxon signed rank sum test with Bonferroni correction. A level of $P<.05$ was accepted as statistically significant.

\section{RESULTS}

Expression of Topo Il $\alpha$ in the Total Cell Population

When analyzed on the total cell population, the median expression of topo II $\alpha$ in all 50 cases was
25\% (IQR 23\%) positive cells. There was no statistically significant difference between the proportion of topo II $\alpha$-positive cells in 21 diploid and 29 nondiploid tumors $(P=.8)$. No statistically significant correlation between the proportion of topo II $\alpha$-positive cells and SPF was reached $(P=.1)$.

Topo Il $\alpha$ in Relation to Cell Cycle Phase in Diploid Tumors

The expression of topo II $\alpha$ in G0/G1 phase and $\mathrm{S} / \mathrm{G} 2 / \mathrm{M}$ phase from 21 diploid tumors is shown in Figure 2. The median expression of positive cells in G0/G1 phase was $26 \%$ (IQR 31\%), compared with $41 \%$ (IQR $29 \%$ ) in $\mathrm{S} / \mathrm{G} 2 / \mathrm{M}$ phase $(P=.002)$. Of all topo II $\alpha$-positive cells, a mean of $65 \%$ (SD 18\%) were in G0/G1 phase (Figure 4). In 18 cases, $>50 \%$ of the positive cells were in G0/G1 phase.

\section{Topo Il $\alpha$ in Relation to Cell Cycle Phase in Nondiploid Tumors}

The expression of topo II $\alpha$ in G0/G1 phase for the diploid cells and G0/G1 phase and S/G2/M phase for the nondiploid cells from 29 nondiploid tumors is shown in Figure 3. The median expression of positive cells in G0/G1 phase for the diploid cells was $9 \%$ (IQR 9\%), compared with 34\% (IQR 30\%) in G0/G1 phase and $60 \%$ (IQR 22\%) in S/G2/M phase 
for the nondiploid cells. These differences were statistically significant $(P<.001)$.

In these nondiploid tumors, the expression in diploid cells in G0/G1 phase was significantly lower than the expression in cells in G0/G1 phase in the diploid tumors $(P=.003)$. Of all topo II $\alpha$-positive cells, a mean of $56 \%$ (SD 15\%) were in nondiploid cells in G0/G1 phase, $12 \%$ (SD 11\%) in nondiploid cells in S/G2/M phase, and $32 \%$ (SD 13\%) in diploid cells in G0/G1 phase (Fig. 4). In 25 cases, $>50 \%$ of the positive cells were in cells in G0/G1 phase.

\section{DISCUSSION}

There is today no established factor for clinical use in prediction of chemotherapy efficacy in breast cancer. SPF and erbB-2, a tyrosine kinase membrane receptor, are two factors that have shown predictive potential. High SPF, a marker of high tumor cell proliferation, has shown positive correlation with response to chemotherapy (2426). Topo II $\alpha$ is also a marker of proliferation, and in a previous study using immunohistochemistry, a good correlation with SPF has been shown (27). In our study, we found no clear correlation between the proportion of topo II $\alpha$-positive cells determined by FCM and SPF.

Patients with tumors expressing high levels of erbB-2 have been shown to benefit from àddition of doxorubicin to L-phenylalanine mustard and 5-FU (28) and from dose-escalated compared with a lowdose combination of cyclophosphamide, doxorubicin, and 5-FU (29). There is however no molecular rationale for a relationship between erbB-2 level and anthracycline efficacy. In a study by Pegram et $a l$. (30), it has been shown that there is no difference in chemosensitivity in vitro or in vivo between erbB-2-negative and transfected breast cancer cells and breast cancer xenografts. Both the erbB-2 gene and the topo II $\alpha$ gene are located close to each other on chromosome 17q. In vitro studies on breast cancer cell lines have shown increased gene copy number for topo II $\alpha$ in two of five erbB-2amplified cell lines. This topo II $\alpha$ amplification was associated with increased topo II $\alpha$ protein expression and increased sensitivity to the topo II inhibitor doxorubicin (31). Co-amplification of these two genes has also been shown in breast cancer samples (31-33). This co-amplification may explain the observed relationship between erbB-2 overexpression and anthracycline efficacy.

In normal cells, topo II $\alpha$ is a marker of proliferation, and expression is restricted to $\mathrm{S} / \mathrm{G} 2 / \mathrm{M}$ phases of the cell cycle. In accordance with this, we also found in this study a significantly higher expression of topo II $\alpha$ in S/G2/M phase than in G0/G1 phase, both in diploid and in nondiploid tumors.
Our results show that in clinical breast cancer samples topo II $\alpha$ is expressed also in the G0/G1 phase. Although the expression is lower than in S/G2/M phase, it might be high enough to have implications for the efficacy of topoisomerase II inhibitors. In fact, in 18 of 21 diploid tumors and in 25 of 29 nondiploid tumors, $>50 \%$ of the topo II $\alpha-$ positive cells were in G0/G1 phase. These results on fresh breast cancer tissue are in accordance with the findings from in vitro studies in which malignant transformation was accompanied by qualitative changes in the expression of topo II $\alpha$ (17). However, the level of topo II $\alpha$ in individual tumor cells in G0/G1 phase may be too low to be detected with immunohistochemistry. This may explain why a study using immunohistochemical analysis of topo II $\alpha$ has failed to predict response to epirubicin in metastatic breast cancer (34).

With a significant expression of topo II $\alpha$ in G0/G1 phase, it can be postulated that topoisomerase II inhibitors exert their action by the same mechanism in nonproliferating as in proliferating tumor cells. These findings may explain why some human neoplasms can be cured with chemotherapy despite the fact that the majority of the tumor cells are in a non-proliferative cell cycle phase. It may be that tumor cells with none or low expression of topo II $\alpha$ in G0/G1 phase, like normal cells, can escape from the topoisomerase II inhibitors and repair the DNA damage, whereas tumor cells with persistent expression of topo II $\alpha$ throughout the cell cycle can not.

In summary, our findings show that topo $\mathrm{II} \alpha$, the key target enzyme of topoisomerase II inhibitors, is significantly expressed in G0/G1 phase of breast cancer cells. This finding may have clinically important implications for treatment efficacy of topoisomerase II inhibitors.

\section{REFERENCES}

1. National Board of Health and Welfare. The Cancer Registry. Cancer incidence in Sweden 1997. Stockholm, Sweden: 1999.

2. National Board of Health and Welfare. Causes of death 1997. Stockholm 1999.

3. Parker SL, Tong T, Bolden S, Wingo PA. Cancer statistics, 1997. CA Cancer J Clin 1997;47(1):5-27.

4. Henderson IC. Chemotherapy for metastatic disease. In: Harris JR, Hellman S, Henderson IC, Kinne DW, editors. Breast diseases. 2nd ed. Philadelphia: Lippincott; 1991. p. 604-65.

5. Roca J. The mechanisms of DNA topoisomerases. Trends Biochem Sci 1995;20(4):156-60.

6. Liu LF. DNA topoisomerase poisons as antitumor drugs. Annu Rev Biochem 1989;58:351-75.

7. Tsai-Pflugfelder M, Liu LF, Liu AA, Tewey KM, Whang-Peng J, Knutsen T, et al. Cloning and sequencing of cDNA encoding human DNA topoisomerase II and localization of the gene to chromosome region 17q21-22. Proc Natl Acad Sci U S A 1988;85(19):7177-81. 
8. Tan KB, Dorman TE, Falls KM, Chung TD, Mirabelli CK, Crooke ST, et al. Topoisomerase II alpha and topoisomerase II beta genes: characterization and mapping to human chromosomes 17 and 3, respectively. Cancer Res 1992;52(1): 231-4.

9. Mirski SE, Evans CD, Almquist KC, Slovak ML, Cole SP. Altered topoisomerase II alpha in a drug-resistant small cell lung cancer cell line selected in VP-16. Cancer Res 1993; 53(20):4866-73.

10. Chen AY, Liu LF. DNA topoisomerases: essential enzymes and lethal targets. Annu Rev Pharmacol Toxicol 1994;34:191218.

11. Nitiss JL, Beck WT. Antitopoisomerase drug action and resistance. Eur J Cancer 1996;32A(6):958-66.

12. Fry AM, Chresta CM, Davies SM, Walker MC, Harris AL, Hartley JA, et al. Relationship between topoisomerase II level and chemosensitivity in human tumor cell lines. Cancer Res 1991;51(24):6592-5.

13. Houlbrook S, Addison CM, Davies SL, Carmichael J, Stratford IJ, Harris AL, et al. Relationship between expression of topoisomerase II isoforms and intrinsic sensitivity to topoisomerase II inhibitors in breast cancer cell lines. Br J Cancer 1995;72(6):1454-61.

14. Withoff S, de Vries EG, Keith WN, Nienhuis EF, van der Graaf WT, Uges DR, et al. Differential expression of DNA topoisomerase II alpha and -beta in P-gp and MRP-negative VM26, mAMSA and mitoxantrone-resistant sublines of the human SCLC cell line GLC4. Br J Cancer 1996;74(12):186976 .

15. Woessner RD, Mattern MR, Mirabelli CK, Johnson RK, Drake FH. Proliferation- and cell cycle-dependent differences in expression of the 170 kilodalton and 180 kilodalton forms of topoisomerase II in NIH-3T3 cells. Cell Growth Differ 1991; 2(4):209-14.

16. Sugimoto K, Yamada K, Egashira M, Yazaki Y, Hirai H, Kikuchi A, et al. Temporal and spatial distribution of DNA topoisomerase II alters during proliferation, differentiation, and apoptosis in HL-60 cells. Blood 1998;91(4):1407-17.

17. Heck MM, Hittelman WN, Earnshaw WC. Differential expression of DNA topoisomerases I and II during the eukaryotic cell cycle. Proc Natl Acad Sci U S A 1988;85(4):1086-90.

18. Hsiang YH, Wu HY, Liu LF. Proliferation-dependent regulation of DNA topoisomerase II in cultured human cells. Cancer Res 1988;48(11):3230-5.

19. Woessner RD, Chung TD, Hofmann GA, Mattern MR, Mirabelli CK, Drake FH, et al. Differences between normal and ras-transformed NIH-3T3 cells in expression of the $170 \mathrm{kD}$ and $180 \mathrm{kD}$ forms of topoisomerase II. Cancer Res 1990; 50(10):2901-8.

20. Kaufmann SH, McLaughlin SJ, Kastan MB, Liu LF, Karp JE, Burke PJ. Topoisomerase II levels during granulocytic maturation in vitro and in vivo. Cancer Res 1991;51(13):3534-43.

21. Yabuki N, Sasano H, Kato K, Ohara S, Toyota T, Nagura H, et al. Immunohistochemical study of DNA topoisomerase II in human gastric disorders. Am J Pathol 1996;149(3):997-1007.
22. Tanoguchi K, Sasano H, Yabuki N, Kikuchi A, Ito K, Sato S, et al. Immunohistochemical and two-parameter flow cytometric studies of DNA topoisomerase II alpha in human epithelial ovarian carcinoma and germ cell tumor. Mod Pathol 1998;11(2):186-93.

23. Bauer KD, Duque RE, Shankey TV, editors. Clinical flow cytometry. Principles and application. Baltimore: Williams \& Wilkins; 1993.

24. Remvikos Y, Beuzeboc P, Zajdela A, Voillemot N, Magdelenat $\mathrm{H}$, Pouillart P. Correlation of pretreatment proliferative activity of breast cancer with the response to cytotoxic chemotherapy. J Natl Cancer Inst 1989;81(18):1383-7.

25. Hietanen P, Blomqvist C, Wasenius VM, Niskanen E, Franssila K, Nordling S. Do DNA ploidy and S-phase fraction in primary tumour predict the response to chemotherapy in metastatic breast cancer? Br J Cancer 1995;71(5):1029-32.

26. Sjostrom J, Krajewski S, Franssila K, Niskanen E, Wasenius VM, Nordling S, et al. A multivariate analysis of tumour biological factors predicting response to cytotoxic treatment in advanced breast cancer. Br J Cancer 1998;78(6):812-5.

27. Jarvinen TA, Kononen J, Pelto-Huikko M, Isola J. Expression of topoisomerase II alpha is associated with rapid cell proliferation, aneuploidy, and c-erbB2 overexpression in breast cancer. Am J Pathol 1996;148(6):2073-82.

28. Paik S, Bryant J, Park C, Fisher B, Tan-Chiu E, Hyams D, et al. erbB-2 and response to doxorubicin in patients with axillary lymph node-positive, hormone receptor-negative breast cancer. J Natl Cancer Inst 1998;90(18):1361-70.

29. Thor AD, Berry DA, Budman DR, Muss HB, Kute T, Henderson IC, et al. erbB-2, p53, and efficacy of adjuvant therapy in lymph node-positive breast cancer. J Natl Cancer Inst 1998; 90(18):1346-60.

30. Pegram MD, Finn RS, Arzoo K, Beryt M, Pietras RJ, Slamon DJ. The effect of HER-2/neu overexpression on chemotherapeutic drug sensitivity in human breast and ovarian cancer cells. Oncogene 1997;15(5):537-47.

31. Jarvinen TA, Tanner M, Rantanen V, Barlund M, Borg A, Grenman S, et al. Amplification and deletion of topoisomerase IIIalpha associate with ErbB-2 amplification and affect sensitivity to topoisomerase II inhibitor doxorubicin in breast cancer. Am J Pathol 2000;156(3):839-47.

32. Smith K, Houlbrook S, Greenall M, Carmichael J, Harris AL. Topoisomerase II alpha co-amplification with erbB2 in human primary breast cancer and breast cancer cell lines: relationship to m-AMSA and mitoxantrone sensitivity. Oncogene 1993;8(4):933-8.

33. Murphy DS, McHardy P, Coutts J, Mallon EA, George WD, Kaye SB, et al. Interphase cytogenetic analysis of erbB2 and topoII alpha co-amplification in invasive breast cancer and polysomy of chromosome 17 in ductal carcinoma in situ. Int J Cancer 1995;64(1):18-26.

34. Jarvinen TA, Holli K, Kuukasjarvi T, Isola JJ. Predictive value of topoisomerase IIalpha and other prognostic factors for epirubicin chemotherapy in advanced breast cancer. $\mathrm{Br} \mathrm{J}$ Cancer 1998;77(12):2267-73. 